\title{
Factors relating to the attraction of talented early career academics in South African higher education institutions
}

\begin{tabular}{|c|c|}
\hline \multicolumn{2}{|c|}{$\begin{array}{l}\text { Authors: } \\
\text { Dorcas L. Lesenyeho }{ }^{1} \\
\text { Nicolene E. Barkhuizen }^{1} \\
\text { Nico E. Schutte }^{1}\end{array}$} \\
\hline \multicolumn{2}{|c|}{$\begin{array}{l}\text { Affiliations: } \\
{ }^{1} \text { Global Innovative Forefront } \\
\text { Talent, North-West } \\
\text { University, South, Africa }\end{array}$} \\
\hline \multicolumn{2}{|c|}{$\begin{array}{l}\text { Corresponding author: } \\
\text { Nicolene Barkhuizen, } \\
\text { nicolene.barkhuizen@ } \\
\text { nwu.ac.za }\end{array}$} \\
\hline \multicolumn{2}{|c|}{$\begin{array}{l}\text { Dates: } \\
\text { Received: } 10 \text { Feb. } 2017 \\
\text { Accepted: } 28 \text { Mar. } 2018 \\
\text { Published: } 25 \text { June } 2018\end{array}$} \\
\hline \multicolumn{2}{|c|}{$\begin{array}{l}\text { How to cite this article: } \\
\text { Lesenyeho, D.L., Barkhuizen, } \\
\text { N.E., \& Schutte, N.E. (2018). } \\
\text { Factors relating to the } \\
\text { attraction of talented early } \\
\text { career academics in South } \\
\text { African higher education } \\
\text { institutions. SA Journal } \\
\text { of Human Resource } \\
\text { Management/SA Tydskrif vir } \\
\text { Menslikehulpbronbestuur, } \\
\text { 16(0), a910. https://doi. } \\
\text { org/10.4102/sajhrm. } \\
\text { v16i0.910 }\end{array}$} \\
\hline \multicolumn{2}{|c|}{$\begin{array}{l}\text { Copyright: } \\
\text { (C) 2018. The Authors } \\
\text { Licensee: AOSIS. This } \\
\text { is licensed under the } \\
\text { Creative Commons } \\
\text { Attribution License. }\end{array}$} \\
\hline \multicolumn{2}{|l|}{ Read online: } \\
\hline 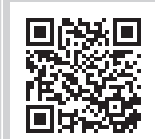 & $\begin{array}{l}\text { Scan this QR } \\
\text { code with your } \\
\text { smart phone or } \\
\text { mobile device } \\
\text { to read online. }\end{array}$ \\
\hline
\end{tabular}

Orientation: South African higher education institutions (HEIs) are facing significant challenges in attracting talents to academic positions.

Research purpose: The main objective of this research was to determine factors that will attract early career academics to South African HEIs.

Motivation for the study: Currently there exists limited research on factors that attract early career academics to HEIs as preferred employers.

Research approach, design and method: A qualitative approach was adopted for this study; semi-structured interviews were conducted to gain data. The study participants comprised of 23 academic staff members from various merged South African HEIs.

Main findings: The findings show that nine themes are related to the attraction of early career academics to HEIs: career development and advancement, opportunities to make a contribution, employer branding and prestige, job security, flexible working hours (work-life balance), intellectual stimulation, innovation, opportunity to apply skills and autonomy.

Practical/managerial implications: The results also challenge HEIs to develop a superior employer brand with a strong employee value proposition (EVP) that would attract, develop and reward early career academics for their work efforts.

Contribution/value-add: The study provides important practical guidelines that could assist HEIs to attract talented early career academics and become an employer of choice.

\section{Introduction}

The ability to attract quality young academics remains a challenge for many South African higher education institutions (HEIs). The recent 'fees-must-fall' campaign by students has tarnished higher education's reputation as an employer of choice significantly (Badat, 2017). Not only were many HEIs' infrastructure demolished, but academics suffered losses in terms of annual salary increases, performance bonuses, lack of quality lecturing time and decreased research productivity. Moreover, the organisational brands of South African HEIs continue to be damaged as a result of the downgrading of their competitive rankings relative to HEIs abroad (Mouton, Louw, \& Strydom, 2013). At the same time, academics contend with a lack of adequate state and research funding, uncompetitive remuneration packages and research incentives, a decline in the quality of the workforce in South Africa as a developing country and employment equity initiatives (The South African Council on Higher Education, 2016). Consequently, tarnished organisational brands present serious barriers to attracting academics in order to ensure an adequate pipeline of academics, which is critical to South Africa's national strategy to accelerate human capital development (Higher Education South Africa, 2014).

Identifying early career academics is not an easy task. According to McAlpine and Akerlind (2010), there are difficulties in trying to determine who early career academics are, what they do and how they develop as academics. Most researchers within higher education concur that research involving early career academics has focused mainly on participants within the first five years or so of their first academic appointment. However, the nature of those appointments varies greatly: from post-doctoral researchers or teaching fellows to probationary academics, pretenured faculty members, to PhD students with teaching responsibilities and/or external grant funding. Gratton (2011) elaborated on the need for generational cohesion and the challenge organisations face in shaping the world of work to make the best of the skills and realise the aspirations of all generations currently in the workplace. 
To date, limited research exists on the factors that would attract early career academics to South African HEIs. Vale (2010) mentioned ten factors that attract people to a career in academia, regardless of the financial implications, which are freedom to choose directions, reinventing oneself throughout one's career, participating in the great era of discovery, being part of an international community joined by common interests, pleasant travels, a social and 'youthful' job, many measures of success, flexible daily schedule, doing some good and scholarship.

In light of the above discussion, the main objective of this research was to determine the factors that will attract early career academics to South African HEIs. This research was motivated by the fact that little research has been conducted on the talent management of early career academics and the factors that attract them to a HEI as a preferred employer.

This article is structured as follows. Firstly, a literature review is presented on the factors that could attract early career academics to HEIs as a preferred employer. Then, the research method applied in the study is presented, followed by the findings of the study. The article concludes with a discussion of the findings and recommendations for future research and practice.

\section{Literature review}

\section{Factors attracting early career academics}

\section{Career development and advancement}

Career management is a critical pillar of work-related outcomes linked to organisational commitment (De Vos, Dewettnick, \& Buyens, 2007). Gong and Chang (2008) stated that organisational opportunities and benefits should make employees feel obliged and committed to an organisation. According to Bhatt (2011), career anchors can assist in managing and steering career development and advancement of academic staff. Career anchors are patterns of selfperceived talents, attitude, motives and values that guide and stabilise a person's career after several years of realworld experience and feedback (Bhatt, 2011). These should be supported by institutional human resource (HR) processes related to developing academic interest, opportunity to improve academic qualifications, availability of promotion opportunities and rapid career advancement opportunities for early career academics. Bhatt further suggested that organisations should revisit the way employees' careers are managed to ensure career development and advancement through planning and organisational career management processes.

Although the concept of career management has received great research attention over the years, the career development of academics has been neglected. Available research shows that the careers of academics can be advanced through a variety of methods, such as mentorship (Thomas, Lunsford, \& Rodrigues, 2015), networking (Ansmann et al., 2014), transnational collaboration (Coldwell, Papageorgiou,
Callaghan, \& Fried, 2016), training and development (Botha \& Potgieter, 2009), opportunities for further education (Schulze, 2015; Tessema, 2009) and promotion opportunities (Bhatt, 2011). Other research also pointed out that career development opportunities in HEIs are hampered by a lack of both government funding (Busch \& Ledingham, 2016) and organisational infrastructure (MacGregor, 2009).

Collaborative research appears to be the appropriate strategy to promote career development of early academics. Kochan and Mullen (in Tynan \& Garbett, 2007) stated that collaboration enriches personal and organisational life as a whole, which is relevant for the development of new academics, regardless of gender. The greatest advantage of collaborative research is that it provides a synergy that gives early career researchers an entry into their field, with fewer mistakes and disappointments and less stress. A study by Singh (2015) showed that capacitybuilding initiatives for a rural South African HEI resulted in an increase in the number of accredited publications by staff members, the number of staff with doctoral qualifications, awareness of funding opportunities and the level of postgraduate supervision output. Other researchers also highlighted the importance of developing e-skills to cater for the digital age of teaching in higher education (Adegbenro \& Gumbo, 2015).

\section{Opportunity to make a contribution}

Public HEIs in South Africa are expected to play a critical role in the development of human resources and in the overall social development and transformation of the continent (Van Heerden, Bohlmann, Giesecke, Makochekanwa, \& Roos, 2007). The success and sustainability of higher education in fulfilling these roles depend on an academic profession that can utilise research, teaching and community engagement in solving problems and harnessing the full economic potential of the continent (Grobbelaar \& De Wet, 2016). Studies have also highlighted the important role of academics in advancing the employability skills of students (Heerde \& Murphy, 2009).

Other research, advocates the growing importance of academic staff involvement in community service projects addressing contemporary societal needs such as those related to HIV and/or AIDS (Sanjobo, Lukwesa, Kaziya, Tepa, \& Puta, 2016). Studies focusing on human-centric occupations, such as education, indicated that individuals join the teaching profession because of the enhanced opportunity to interact with students and make a contribution towards the improvement of their lives (Strauss, 2012). In addition, academics are also challenged to advance their subject matter expertise to meet the knowledge requirements of the 21st century workplace (Du Preez, 2015; Ondari-Okemwa, 2011).

Pienaar and Bester (2008) stated that the opportunity to make a meaningful contribution should not only be limited to student involvement, the community and the body of knowledge in a field. Academics should be allowed to make contributions based on performance goals that are part of the job description and receive rewards in the form of bonuses, promotions, salary increases and recognition. 


\section{Organisational branding, prestige and employee value proposition}

Higher education institutions are paying more attention to their marketing and branding functions because of the shortage of quality academic staff (Hanover Research, 2014). An employment brand reflects the extent to which a workplace values its employees. An employment brand represents an organisation's employee value proposition (EVP), which includes the gains that staff members enjoy in return for their efforts in the workplace. According to Black, Manohar and Stehli (2013), there are four categories of benefits that represent $80 \%$ of what employees care about: leaders, the company, the job and the rewards.

A study by Annapoorna (2015) among management colleges in Turkey showed that factors such as attractive salary, popularity of the institution, career growth, supportive work environment, recognition of work and work-life balance represent a compelling employment brand. Saurombe, Barkhuizen and Schutte (2017) found that higher educational managers believe that factors such as reputation and image, organisational culture and identity, strategic vision, corporate social responsibility and work and surrounding environment are core to establish a compelling employment brand for talented academics. A study by Lichy and Pon (2015) showed that the opportunity for academics to make their own decisions regarding their work enhanced their perceptions of the employer brand of French Business Schools.

\section{Flexible working hours (work-life balance)}

University teaching has traditionally been viewed as a relatively stress-free occupation (Fisher, 1994). Although not highly paid in comparison to that of professionals in the commercial sector, academics have been envied for their tenure, light workloads, flexibility, perks such as overseas trips for study and/or conference purposes, and freedom to pursue their own research (Gillespie, Walsch, Winefield, Dua, \& Stough, 2001). According to Padmasiri and Mahalekamge (2016), balancing work and family life is an important factor in the personal and career development of academics. Work-life conflict occurs when work and non-work demands are incompatible (Rana \& Panchal, 2014). Bell, Rajendran and Theiler (2012) found that escalating stress and pressures related to the changing higher educational environment affects the work-life balance of academic staff. A study by Noor (2011) showed that satisfaction with work-life balance was a significant predictor of academic turnover intentions in Malaysian public HEIs.

\section{Intellectual stimulation and innovation}

According to Goff (2008), talent includes the right combination of inborn abilities, complemented by the knowledge, skills, attitudes (competence) and experience needed to perform in a given situation. Talented employees should therefore be seen not only as human capital but also as custodians of the success of their organisation through the implementation of their attributes (Foreman, 2007). Organisations should create an environment within which employees will spontaneously want to share their human capital and talents. Bendaraviciene, Kristolatitis and Turauskas (2013) found that academic work is largely driven by interesting, intellectually challenging work, attentive supervision and good relations. Moreover, the industry requires academics to become more innovative in terms of knowledge sharing and dissemination to facilitate learning (Barrett, 2011). Turner et al. (2017) indicated the need of continuous professional development in teaching innovation for academic staff to meet the increasing educational demands of students.

\section{Job security}

Job insecurity has become a key aspect of South African HEIs as a result of continuous transformation and merger processes (Tlou, 2014). Results on the job security of academic staff are mixed and confounding. A study by Tessema (2009) showed that the availability of job opportunities in HEIs in Ethiopia increased the feelings of job security of academic staff members. However, the results of this study showed that increases in job opportunities and subsequent higher student enrolments worsened working conditions of academic staff as they are faced with increased workloads and extended work schedules. In South Africa, Pienaar and Bester (2008) found that job insecurity was a career obstacle for academic staff members. Schulze (2008) found that a lack of job security had an adverse impact on the quality of research outputs produced by academic staff members in a selected South African HEI. Viljoen and Rothmann (2009) found that stress about job security negatively affected the health of academic staff members in a South African university of technology.

\section{Autonomy}

Autonomy refers to the opportunity to be able to make decisions and implement them with little or no interference by authorities. For academics, autonomy includes being allowed to teach and conduct research within their niche areas of interest, with all the required flexibility (Stromquist, 2017). According to Schmidt and Landberg (2008), academic freedom and autonomy are fundamental values of universities, as these affect all aspects of academic activity. These authors further stated that autonomy can include the opportunity to teach without external influences and choosing one's own research projects and publication methods.

A study by Clare and Sivil (2014) showed that transformation of South African HEIs has increasingly brought academics under surveillance and has significantly eroded their autonomy as individuals. Ekundayo and Adedokun (2009) found that several factors can erode autonomy, such as the appointment of a vice chancellor, erosion of the powers of the senate as a supreme body in academic matters and the issue of quota systems that force universities to take in students irrespective of whether they qualify for admission. Amarasena, Ajward and Ahasanul Haque (2015) found that a lack of autonomy furthermore has a significant impact on academic staff satisfaction in government universities in Sri Lanka. 


\section{Research design Research approach}

A qualitative approach was adopted for this study because the emphasis was to bring forth the expectations and experiences of early academics in a holistic and in-depth manner. According to Vishnevsky and Beanlands (2004), this represents an exploratory analysis. Furthermore, Kearney (quoted in Vishnevsky \& Beanlands, 2004) stated that an excellently pre-arranged and well-conducted qualitative research study serves as a reliable and rich source of knowledge that can be implemented by providing exploratory information about a phenomenon, promoting insight and awareness of human experience and supporting the development of formal frameworks and tools.

The present study took an interpretivist approach, which involved integrating human interest and experiences for interpretation (Rubin \& Rubin, 1995). This approach is considered suitable for qualitative evaluative research because it is particularly useful in intensive, small-scale research (Walker \& Dewar, 2000). Researchers have argued that this approach should include a theoretical framework providing guidance on how to shape meaning derived from a particular belief into interpretable knowledge. Alvarez (2003) stated that the interpretivist method provides possibilities for generating fresh insights because it points out different facets of organisational phenomena and can produce markedly different and uniquely informative theoretical views of events. Descriptive or interpretive data analysis for a positivist method provides sufficient evidence, enabling clear, credible and convincing claims or interpretations.

\section{Research strategy}

A case study was the strategic approach used in this study. One of the advantages of a case study is that it is more descriptive and exploratory in nature and less explanatory. This approach was considered appropriate for the present study because, according to Yin (2003), the empirical element of a case study method presents a phenomenon in a real-life context. Silverman (2000) stated that a case study's data analysis involves an iterative, spiralling or cyclical process that proceeds from a more general perspective to more specific observations that can be generalised.

The approach for the present researcher was to generate and integrate themes derived from the group interviews, in conjunction with the conducted literature review. Munsamy and Bosch Venter (2009) postulated that this approach is reliable and works consistently with the modernistic interpretivist strategy.

\section{Research setting}

The setting for this research was a selected merged South African HEI. The set HEI came into being as part of the South African government's plan to transform higher education.

\section{Research method}

\section{Entrée and establishing researcher roles}

Permission for the project was first obtained from the Head of Skills Development of the Higher Education Department of the Government of South Africa. Further permission to conduct interviews with early career academics was obtained from the relevant authorities of the selected higher education such as the vice rector of research. The participants were informed of the purpose of the study and that participation was voluntary and anonymous.

\section{Sampling}

The sample for this study included early career academics from a selected merged South African HEI.

The following criteria were used to select the sample: participants must have between 1 and 15 years of experience, be research novices and could be from any race and gender. According to Neuman (2003), purposive sampling, as was adopted in the present study, enhances the understanding of what will be presented by the respondents and assists in developing theories and concepts. Vishnevsky and Beanlands (2004) stated that, in qualitative research, the sample size is infrequently predetermined, and the researcher can include as many respondents as necessary to gain a comprehensive understanding of a phenomenon. In the present study, participants were chosen based on their qualifications and experience (Cooper, 2006), with a focus on who could provide the information needed for this study.

The participants comprised of 23 early career academics from a selected merged South African HEI. The demographic characteristics of the participants are presented in Box 1 .

Most of the participants were males $(N=15)$, employed as lecturers $(N=16)$, had a master's degree qualification $(N=13)$ and were representative of the black African ethnic group $(N=14)$.

\section{Data collection}

Data were collected through individual and group interview sessions. The interviews were conducted using structured questions, allowing consistency throughout the interviews. According to Neuman (2003), structured questions assist the researcher in guiding participants in their discussions, which allow for the systematic collection of data on a defined area of interest.

\section{Data recording and storing}

The interviews were tape-recorded, which served as a backup system during data analysis. This helped to ensure that the researcher did not draw incorrect conclusions from responses. Extensive notes were taken, allowing recording of reactions to information by the participants. Rubin and Rubin (1995) stated that the above method gives respondents an indication that their input is important. The notes taken during the interviews provide the researcher with an 
BOX 1: Demographic characteristics of interview participants.

P1 Participant 1 was a white, male junior lecturer who had only 3 years of experience as an academic. He had joined the HEl because he had a passion for research, publication and interacting with students. He had an honours degree and was in the process of completing his master's degree in industrial psychology.

P2 Participant 2 was a white, female junior lecturer who had only 1 year of experience as an academic. She had become an academic to further her studies and pursue a career as a lecturer. She had an honour's degree and was about to complete her master's degree in industrial sociology.

P3 Participant 3 was a white, male lecturer with 5 years of experience as an academic. He had joined the HEl because he felt it offered opportunities to be creative and innovative, without much restriction. He held a master's degree in industrial psychology and was pursuing his PhD.

P4 Participant 4 was a white, male lecturer with 8 years of experience as an academic. He had joined the HEl because he had a passion for research and publication. He held a master's degree in sociology and was pursuing his PhD degree. He was a programme director, responsible for academic programmes.

P5 Participant 5 was an Indian, female lecturer with 6 years of experience as an academic. She had been requested to assist students as an SI and had subsequently developed a passion for being an academic. She held a master's degree in economics and was pursuing her PhD.

P6 Participant 6 was a white, female lecturer with 6 years of experience as an academic. She had joined the HEl because she had a passion for teaching, research and publication. She held a master's degree in economics and was pursuing her PhD.

P7 Participant 7 was a black African, male lecturer with 10 years of experience as an academic. He had joined the HEI because he had a passion for teaching, research and networking. He held a master's degree in human resource management (HRM) and was pursuing his PhD.

P8 Participant 8 was a black African, male lecturer with 15 years of experience as an academic. He had joined the HEI because he had a passion for teaching. He held a master's degree in HRM and was not sure if he wanted to complete a PhD.

P9 Participant 9 was a black African, male lecturer with 3 years of experience as an academic. He had joined the HEl because he had a passion for developing young people and networking. He held a master's degree in management and was pursuing his PhD.

P10 Participant 10 was a white, female lecturer with 8 years of experience as an academic. Her passion was teaching and developing young people. She held a master's degree in transport economics and was a programme director. She was pursuing her PhD.

P11 Participant 11 was a white, male professor with 15 years of experience as an academic. He had joined the academic world because of an interest in research and teaching. He held a doctorate degree in economics.

P12 Participant 12 was a black African, female professor with 10 years of experience as an academic. She had joined the academic world because of a lack of other job opportunities. She was busy with her post-doctoral research.

P13 Participant 13 was a black African, male junior lecturer who had 2 years of experience as an academic. He had joined the HEl because he had a passion for teaching and he subsequently developed an interest in research. He held an honours degree in statistics and was pursuing his master's degree.

P14 Participant 14 was a black African, female lecturer who had 8 years of experience as an academic. She had joined the university to pursue her passion for teaching and to gain opportunities to further her studies. She held a master's degree in statistics and was awaiting the results of her PhD.

P15 Participant 15 was a black African, female senior lecturer who had 20 years of experience as an academic, but was a novice at research. She had joined the university to pursue her passion for teaching and to gain opportunities to further her studies. She had developed an interest in research and publication. She held a master's degree in HRM and was about to complete her PhD.

P16 Participant 16 was a black African, male lecturer with only 1 year of experience as an academic. He had joined the HEI because if offered better conditions of service. He had 8 years of experience as a secondary school teacher. He held a master's degree in management and was pursuing his PhD.

P17 Participant 17 was a black African, male lecturer with 2 years of experience as an academic. He had joined the HEl because he had desired a different work environment. He held a master's degree in management and was pursuing his PhD.

P18 Participant 18 was a black African, male lecturer with 1 year of experience as an academic. He had joined the HEl because it offered better conditions of service. He had 8 years of experience as a secondary school teacher. He held a master's degree in management and was pursuing his PhD.

P19 Participant 19 was a white, male professor with 15 years of experience as an academic. He believed that the university was the most conducive environment for growth and development. He held a PhD in psychology and his passion was research and publication, especially books. He was also a programme director.

P20 Participant 20 was a black African male with 8 years of experience as an academic lecturer. He had joined the HEl because it offered opportunities for further study and because he had a passion for teaching. He held a PhD in management. He was interested in research and research supervision and was also responsible for programme co-ordination.

P21 Participant 21 was a black African male with 8 years of experience as a senior lecturer. He had joined the higher education department because of lack of staff in the unit. He held a PhD in public administration. His focus was on research and publication as a requirement for promotion in the institution.

P22 Participant 22 was a black African, female student lecturer. Her decision to join the academic world was influenced by a love for teaching and interacting with young people, as well as a lack of other job opportunities. She held an honours degree in industrial relations and was pursuing her master's degree.

P23 Participant 23 was a black African, male student lecturer who had joined academia because of a lack of other employment opportunities. He held an honours degree in industrial relations and was pursuing his master's degree.

opportunity to monitor the process of data collection and subsequent data analysis.

\section{Ensuring the quality and rigour of the research}

In this study, the recorded interviews of both the individual and the group sessions were transcribed. Although there were challenges in transcribing all the recordings, all efforts were directed at ensuring that all relevant and important information was captured to ensure the accuracy of data analysis. The quotes provided were verbatim. In creating a framework for analysis, the researcher extracted themes and subthemes for the categorisation of information from the transcripts. Saunders, Lewis and Thornhill (2003) stated that this method allows the altering of themes and subthemes or relationships in the re-arranged data while searching for more information in the data. Furthermore, this method allows for the identification of missing statements and justification of the alterations to the original implementation scheme, while allowing an up-to-date definition of each theme and subtheme, to sustain consistency during data capturing and analysis (Saunders et al., 2003).
The approach to the analysis entailed the researcher counting how many respondents mentioned the same issue, which is supported by Seidman (2012).

\section{Reporting}

The findings of this research are reported in a table. The themes and subthemes extracted from the interviews are substantiated by direct quotes. This method is in line with the suggestion of Cresswell (2009) that a researcher should seek for support that a conclusion applies in a specific research context.

\section{Ethical consideration}

Ethical clearance was obtained before the commencement of the research.

\section{Findings}

Table 1 presents the themes that emerged from the interview sessions and the frequency with which the themes emerged. The researcher identified nine themes from the combined 
TABLE 1: Frequency of themes.

\begin{tabular}{llc}
\hline Variable & Themes & Frequency \\
\hline Theme 1 & Career development and advancement & 23 \\
& Development in area of academic interest & 7 \\
& Opportunity to improve academic qualifications & 6 \\
& Availability of promotional opportunities & 6 \\
& Rapid career advancement opportunities & 6 \\
Theme 2 & Opportunity to make a contribution & 10 \\
& Contribution to students & 4 \\
& Contribution to community & 3 \\
Theme 3 & Contribution to knowledge society & 3 \\
Theme 4 & Job security & 4 \\
Theme 5 & Flexible working hours (work-life balance) & 2 \\
Theme 6 & Intellectual stimulation & 2 \\
Theme 7 & Innovation & 2 \\
Theme 8 & Opportunity to apply skills & 2 \\
Theme 9 & Autonomy & 1 \\
\hline
\end{tabular}

responses of the participants. From the table it is evident that career development and advancement, opportunities to make a contribution and employer branding and prestige were the themes that occurred most often.

\section{Theme 1: Career development and advancement}

Combined themes relating to career development and advancement occurred most often in this study. The participants mentioned that they were attracted to higher education by the opportunity to develop in an area of their research interest, for example, teaching. Some of the participants were more interested in establishing themselves as researchers. One of the participants stated:

'There are a lot of structures and interventions that is available through the university, so I would like to develop as a researcher very strongly. I've got a really clear picture of what it is that I want to do in my research going into the future. The university offers a number of fantastic opportunities for you to develop'. (Participant 11, male, lecturer, master's degree)

Other participants highlighted their interest in becoming educators. One participant stated:

'The thing that influenced me was this urge of contributing towards the educational and academic development. And then, also, to fulfil my need, my personal need as an educator'. (Participant 7, male, senior lecturer, doctorate degree,)

The participants furthermore highlighted that opportunities should be created to attract students to academic positions. One of the participants stated:

'We can grow our team by developing those good students who obtain Master's and PhDs to become junior academics'. (Participant 12, female, lecturer, master's degree)

The participants also mentioned the availability of promotional opportunities and rapid career advancement as factors that would attract them to academia:

'The university systems are unlike the systems in government, where it is on [sic] the availability of the post, but, in academia, people get promoted depending on certain qualifications and meeting certain requirements'. (Participant 1, male, senior lecturer, doctorate degree)

Participant 1 also mentioned about opportunities for rapid career advancement and the benefits associated with it:

'Yes, if they are ready to work, it is an earlier way you can rapidly progress ... for every stage that you are promoted to, you definitely get better packages associated with it'.

Another participant mentioned:

'For PhD, definitely, because that was the ultimate of getting my $\mathrm{PhD}$, and then I ... from here, it is now associate professor and then professor, and where else would you go then to a university'? (Participant 10, female, senior lecturer, doctorate degree)

The above comment was supported by Participant 2:

'For now, I'm really very busy with the $\mathrm{PhD}$, and I think one is going to continue until you get to the highest level, to the professorship, and, when you get there, many opportunities open up for you'. (Participant 2, female, lecturer, master's degree)

The participants also highlighted the opportunity to extend their educational qualifications as a reason for joining higher education. One participant stated:

'I think the opportunity to further my own studies and the fact that I have a passion to work with young people. I want to make a difference'. (Participant 10, female, senior lecturer, doctorate degree)

\section{Theme 2: Opportunities to make a contribution}

Combined themes related to opportunities to make a contribution occurred as the second most theme (mentioned ten times). These participants mostly joined higher education to make a difference in the lives of their students. One participant told:

'The interest of being an academic started when I was a supplementary instructor, so that's where I got my basis of being able to interact with students. I actually started loving the whole idea of being able to help students and the appreciation that you also get from the students, that's what motivated me to study further to become an academic'. (Participant 3, male, junior lecturer, honours degree)

In support of the above statement, Participant 5 added:

'Number 1 is my interest in empowering the students and making a difference and also inspiring them ... Number 2 is more careerwise... Number 3 is all about passion. I'm not here by chance, I'm here by choice'. (Participant 5, female, lecturer, master's degree)

The participants were also attracted to higher education to make a difference to the broader community and knowledge society. In this regard, some participants stated:

'The benefits are... it gives me a sense of knowing that I make a particular contribution towards the social economic development of our young and old. (Participant 7, male, senior lecturer, doctorate degree)

and

'It's nice to be called to give lecturers' interviews, telling the whole world what certain issues are by giving you an opportunity 
to express your views. You have an opportunity to show what you have and who you are'. (Participant 2, female, lecturer, master's degree)

\section{Theme 3: Employer brand and prestige}

Employer branding and prestige was the theme that occurred third most (mentioned four times). Some of the participants stated:

'We must become the university, an employer, of choice, so that if you are an employer of choice, your employees are going to show commitment and engagement, and it seems as we are on that way. I hope that we are going to continue in a manner of building our branding'. (Participant 10, female, senior lecturer, doctorate degree)

and

'I think the money aspect is not very attractive, but, comparatively, we will say the financial reward also makes one feel like joining here, and the prestige attached. At least, nobody would see you as an ordinary teacher and lecturer'. (Participant 2, female, lecturer, master's degree)

\section{Other themes}

Other themes that were mentioned to a lesser extent included job security, flexible working hours (work-life balance) and intellectual stimulation (all mentioned twice), and opportunity to apply skills and autonomy (both mentioned once). The participants in this sample experienced job security because of contractual obligations to their institution, related to their studies.

One of the participants stated:

\begin{abstract}
'...because of a certain contract we signed, that we have to be here for a certain number of years... we have already taken up some grants from the university, which we need to stay for about 4 or 5 years'. (Participant 2, female, lecturer, master's degree)
\end{abstract}

One of the participants mentioned flexible working hours and a sense of belonging to her department:

'Flexibility, as well... There's flexibility in terms of, you know, when you're at a 95-drop. Here it's more flexible, and growth, as well, in your department. You get so recognised that you just feel at home. You become a part of the family, and I think that is what you want the most'. (Participant 3, male, junior lecturer, honours degree)

The participants indicated that they were intellectually stimulated by the opportunity to gain knowledge. In this regard, one participant noted:

'I think, for me, it's all about trying to get as much knowledge as I can when it comes to academics, so, that's why I'm just pushing up until I get tired. Once getting that knowledge, I will impart it to other people'. (Participant 4, male, junior lecturer, honours degree)

\section{Discussion}

The main objective of this research was to determine the factors that would attract early career academics to
South African HEIs. The participants identified nine factors that could be instrumental in the attraction of early career academics: career development and advancement, opportunities to make a contribution, employer branding and prestige, job security, flexible working hours, intellectual stimulation, innovation, opportunity to apply skills and autonomy.

Career development and advancement was the practice that appeared to be the main factor in attracting early career academics to HEIs. The participants further mentioned specific needs, such as development in their area of academic interest, opportunities to improve their academic qualifications, the availability of promotional opportunities and rapid career advancement opportunities, as important for their career development. Although the HEIs had sufficient research infrastructures available (see Singh, 2015), higher education management should create career development opportunities, such as mentorship, networking, transnational collaboration, specific training and development for teaching, and promotion opportunities that will assist novice scholars to become teachers and researchers of excellence (see Ansmann et al., 2014; Botha \& Potgieter, 2009; Coldwell et al., 2016; Schulze, 2015; Thomas et al., 2015). Some participants also indicated the benefit of the possibility of obtaining further qualifications as part of being an employee at a HEI (Bhatt, 2011).

Opportunity to make a contribution occurred second most in this study. The participants specifically indicated that they wanted to make a contribution to students' lives, their community and the knowledge society. These findings indicate that these academics had clarity regarding the career expectations of an academic scholar and the purpose of their role as an academic (Grobbelaar \& De Wet, 2016; Van Heerden et al., 2007). As found in previous research, the participants in this sample enjoyed interacting with students. They were also aware of social problems that students were exposed to, and were interested in empowering them to make a better life for themselves (Strauss, 2012). The participants also believed that the knowledge that they were disseminating could make a significant contribution towards enhancing the broader society (Pienaar \& Bester, 2008).

Employer branding and prestige emerged as the third most important factor. The participants highlighted the need for higher education to improve its employer brand to ensure commitment by employees. These results are in line with the findings of Hanover Research (2014), which indicated that HEIs should continue to improve their brand to attract quality academic staff. The participants also highlighted the improvement of the EVP of HEIs so that academics are rewarded sufficiently for their work efforts (Saurombe et al., 2017).

The factors that were mentioned to a lesser extent included job security, flexible working hours, intellectual stimulation, innovation, opportunity to apply skills and autonomy. In line with previous research it appears that early career academics do not perceive higher education as an employer that 
will provide job security (see Schulze, 2008; Viljoen \& Rothmann, 2009). In the present study, autonomy was also not highlighted as a factor in the attraction of early career academic staff. One possible explanation is that, unlike their senior colleagues, novice researchers do not yet have the responsibility to make independent decisions about their research endeavours (Schmidt \& Landberg, 2008). The findings of the present study further confirm the importance of opportunity to apply skills and intellectual stimulation (see Foreman, 2007). In contrast with previous studies, the early career academics in the present study did not consider work-life balance as a factor that would attract them to a HEI (Padmasiri \& Mahalekamge, 2016).

\section{Practical implications}

This research makes important practical contributions. Firstly, it sheds light on the factors that will attract a new generation of early career academics to South African HEIs. These findings challenge some traditional notions, suggesting that work-life balance and autonomy are not the main factors that would attract early career academics to higher education. From a practical point of view, this study therefore challenges the traditional structures of HEIs and indicates that HEI management should adopt talent management practices that cater for the diverse needs of early career academics. The results also challenge HEIs to develop a superior employer brand with a strong EVP that would attract, develop and reward early career academics for their work efforts.

\section{Limitations and recommendations}

This research has some limitations. Firstly, the data consisted only of the perceptions of early career academics. As a result, the findings cannot be generalised to other academics. Secondly, the study focused on the academic profession and thus the findings cannot be generalised to other industries. Thirdly, the lack of research on the attraction of early career academics posed challenges in interpreting the results.

For future research, it is recommended that HEI managers should also be included in the sample in order to determine their perceptions of talent attraction, compared to those of academics. Likewise, a comparative study could be conducted between different academic groups to gain a holistic perspective on the factors that could attract academic staff to South African HEIs. It is also recommended that more research should be conducted on the attraction of academics for purposes of theory building.

\section{Conclusion}

This research provided important information on the factors that will attract early career academics to HEIs. As mentioned previously, the findings of this study challenge traditional knowledge and practices of recruitment in HEIs. Therefore, it is advisable that HEI management and HR departments redevelop talent management practices to ensure that the best-quality novice scholars are attracted, developed and retained in support of the sustainability and competitiveness of South African HEIs.

\section{Acknowledgements Competing interests}

The authors declare that they have no financial or personal relationships that may have inappropriately influenced them in writing this article.

\section{Authors' contributions}

D.L. is a PhD student and this article is based on her PhD thesis. She compiled the article. N.E.B. was the supervisor and N.E.S. was the co-supervisor of this study, and both provided editorial inputs for the article.

\section{References}

Adegbenro, B.J., \& Gumbo, T.M. (2015). Exploring the conceptual relations between teachers' procedural functional knowledge and pedagogical content knowledge. South African Journal of Higher Education, 29(5), 29-47.

Annapoorna, M.S. (2015). A study on employer branding with reference to higher education sector in Tumkur city with special focus on management colleges Tumkur city. International Multidisciplinary E-Journal, 4(8), 285-294.

Ansmann, L., Flickinger, T., Barello, S., Kunneman, M., Mantwill, S., Quilligan, S., .. Aelbrecht, K. (2014). Career development for early career academics: Benefits of networking and the role of professional societies. Patient Education and Counseling, 97, 132-134. https://doi.org/10.1016/j.pec.2014.06.013

Alvarez, S. (2003). Towards an interpretative integrative framework to conceptualise social processes in large information systems implementations. Information Technology for Development, 10, 233-247. https://doi.org/10.1002/itdj. 1590100403

Amarasena, T.S.M., Ajward, A.R. \& Ahasanul Haque, A.K.M. (2015). The effects of demographic factors on job satisfaction of university faculty members in Sri Lanka. International Journal of Academic Research and Reflection, 3(4), 89-106.

Badat, S. (2017). Deciphering the meanings, and explaining the South African Higher Education student protests of 2015-16. Unpublished research paper.

Barrett, B. (2011, October). International conference on intellectual capital, knowledge management \& organisational learning. Paper published in the peer reviewed Conference Proceedings of the 8th International Conference on Intellectual Capital, Knowledge Management \& Organisational Learning, pp. 75-82. Reading, UK: Academic Publishing Ltd.

Bell, A.S., Rajendran, D., \& Theiler, S. (2012). Job stress, well-being, work-life balance and work-life conflict among Australian academics. Electronic Journal of Applied Psychology, 8(1), 25-37.

Bendaraviciene, R., Kristolatitis, R., \& Turauskas, L. (2013). Exploring employer branding to enhance distinctiveness in higher education. European Scientific Journal, 9(19), 45-78.

Bhatt, A.S. (2011, July). A career anchor perspective of employees in a large company. In 2011 International Conference on Advancements in Information Technology (pp. 265-270). With workshop of ICBMG 2011. IPCSIT Vol. 20 (2011) (2011). Singapore: IACSIT Press.

Black, J.S., Manohar, M., \& Stehli, S. (2013). The war for leadership talent: Creating a superior employee value proposition. Lausanne, Switzerland: International Institute of Management Development.

Botha, L.S., \& Potgieter, F.J. (2009). Understanding skills development in South African Higher Education Institutions. South African Journal of Higher Education, 23(2), $28-45$.

Busch, R., \& Ledingham, M. (2016). Bothered bloggings and troubled tweets: Constructions of stress and concerns for early-career academics. First International Conference on Advanced Business and Social Sciences, 1, 1-12.

Clare, J., \& Sivil, R. (2014). Autonomy lost: The bureaucratisation of South African HE. South African Journal of Higher Education, 28(1), 60-71.

Coldwell, D. Papageorgiou, E., Callaghan, C., \& Fried, A. (2016). Academic citizenship and wellbeing: An exploratory cross-cultural study of South African and Swedish academic perceptions. South African Journal of Education, 30(1), 80-105. https:// doi.org/10.20853/30-1-555

Cooper, D. (2006). Knowledge workers. Canadian Business, 79, 1-2.

Cresswell, J.W. (2009). Research design: Qualitative, quantitative and mixed methods approaches (3rd ed.). Thousand Oaks, CA: Sage.

De Vos, A., Dewettinck, K., \& Buyens, D. (2007). To more or not to move? The relationship between career management and preferred career moves. Employee Relations, 30(2), 156-175. https://doi.org/10.1108/01425450810843348

Du Preez, R. (2015). Towards a 21st century university: Teachings from consumer behaviour applicable to higher education. South African Journal of Higher Education, 29(5), 140-155. 
Ekundayo, H.T., \& Adedokun, M.O. (2009). The unresolved issue of university autonomy and academic freedom in Nigerian universities. Humanity and Social Sciences Journal, 4(1), 61-67.

Fisher, S. (1994). Stress in academic life: The mental assembly line. Buckingham: Open University Press.

Foreman, D.C. (2007). Harnessing the elusive asset: Developing intangible organizational capital. Retrieved March 20, 2016, from http://www.workinfo.com/ free/Downloads/libraryPaper_9864.pd

Gillespie, N.A., Walsh, M., Winefield, A.H., Dua, J., \& Stough, C. (2001). Occupational stress in universities: Staff perceptions of the causes, consequences and moderator of stress. Work and Stress, 15, 53-72. https://doi.org/10.1080/02678370117944

Goff, S. (2008). Finding, developing and managing project talent: In today's top enterprises, everyone's a talent scout. Retrieved March 12, 2017 from www. ProjectExperts.com

Gong, Y., \& Chang, S. (2008). Institutional antecedent and performance consequences of employment security and career advancement practices: Evidence from the People's Republic of China. Human Resource Management, 47(1), 33-48. https:// People's Republic of China. Hum
doi.org/10.1002/hrm.20196

Gratton, L. (2011). Workplace 2025 - What will it look like? Organizational Dynamics, 40(4), 246-254. https://doi.org/10.1016/j.orgdyn.2011.07.002

Grobbelaar, S., \& De Wet, G. (2016). Exploring pathways towards an integrated development role: The University of Fort Hare. South African Journal of Higher Education, 30(1), 162-187. https://doi.org/10.20853/30-1-558

Hanover Research. (2014). Trends in higher education marketing, recruitment and technology. Retrieved December 05, 2016 from http://www.hanoverresearch.com/ media/Trends-in-Higher-Education-Marketing-Recruitment-and-Technology-2.pdf

Heerde, J., \& Murphy, B. (2009). Work-integrated learning: An annotated bibliography of recently published refereed journal articles (2000-2008). Melbourne, Australia: Deakin University.

Higher Education South Africa. (2014). Remuneration of academic staff at South African universities: A summary report of the HESA statistical study of academic remuneration. Pretoria, South Africa: Higher Education South Africa.

Lichy, J., \& Pon, K. (2015). For better or for worse: The changing life of academic staff in French business schools. Journal of Management Development, 34(5), 536-552. in French business schools. Journal of Managem
https://doi.org/10.1108/JMD-03-2014-0022

MacGregor, K. (2009, August 16). South Africa: Shocking results from university tests. University World News. Retrieved from http://www.universityworldnews.com/ article.php?

McAlpine, L., \& Akerlind, G. (2010). Becoming an academic: International perspectives. Basingstoke, UK: Palgrave Macmillan.

Mouton, N., Louw, G.P., \& Strydom, G.L. (2013). Present-day dilemmas and challenges of the South African tertiary system. International Business \& Economics Research Journal, 12(13), 285-300.

Munsamy, M., \& Bosch Venter, A. (2009). Retention factors of management staff in the maintenance phase of their careers in local government. SA Journal of Human Resource Management/SA Tydskrif vir Menslikehulpbronbestuur, 7(1), 1-9. https:// doi.org/10.4102/sajhrm.v7i1.198

Neuman, W.L. (2003). Social research methods: Qualitative and quantitative approaches. Boston, MA: Pearson Education.

Noor, K.M. (2011). Work-life balance and intention to leave among academics in Malaysian Public Higher Education Institutions. International Journal of Business and Social Science, 2(11), 240-248.

Ondari-Okemwa, E. (2011). Knowledge production and distribution by institutions of higher learning in Sub-Saharan Africa: Opportunities and challenges. South African Journal of Higher Education, 25(7), 1447-1469.

Padmasiri, M.K.D., \& Mahalekange, W.G.S. (2016). Impact of demographical factors on work life balance among academic staff of university of Kelaniya, Sri Lanka. Journal of Education and Vocational Research, 7(1), 54-59.

Pienaar, C., \& Bester, C.L. (2008). The retention of academics in the early career phase: Empirical research. SA Journal of Human Resource Management, 6(2), 32-41.

Rana, S., \& Panchal, S. (2014). Work life balance of academic sector employees: A study in Vadodara City. Indian Journal of Applied Research, 4(6), 290-201. https:// doi.org/10.15373/2249555X/June2014/91

Rubin, H., \& Rubin, I. (1995). Qualitative interviewing: The art of hearing data. Thousand Oaks, CA: Sage.
Sanjobo, N., Lukwesa, M., Kaziya, C., Tepa, C., \& Puta, B. (2016). Evolution of HIV and AIDS programmes in an African institution of Higher Learning: The case of the Copperbelt University in Zambia. Open Aids Journal, 10, 24-33. https://doi.org/ Copperbelt University in Zambia.

Saunders, M., Lewis, P., \& Thornhill, A. (2003). Research methods for business students. London: Pearson Education Limited.

Saurombe, M., Barkhuizen, E.N., \& Schutte, N. (2017). Management perceptions of a higher educational brand for the attraction of talented academic staff. South African Journal of Human Resource Management, 15, 1-10. https://doi.org/10.4102/ sajhrm.v15i0.831

Schmidt, E.K., \& Langberg, K. (2008). Academic autonomy in a rapidly changing higher education framework. European Education, 39(4), 80-94. https://doi.org/10.2753/ EUE1056-4934390406

Schulze, S. (2008). Academic research at a South African Higher Education Institution: Quality issues. South African Journal of Higher Education, 22(3), 629-643.

Schulze, S. (2015). The doctoral degree and the professional academic identity development of female academics. South African Journal of Higher Education, 29(3), 260-276.

Seidman, I. (2012). Interviewing as qualitative research: A guide for researchers in education and the social sciences. New York: Teachers College Press.

Silverman, D. (2000). Doing qualitative research: A practical handbook. London: Sage.

Singh, R.J. (2015). Current trends and challenges in South African higher education. South African Journal of Higher Education, 29(3), 1-7.

Strauss, M. (2012). Talent attraction and retention of quality secondary school teachers to the rural areas of the Northern Cape province of South Africa. Dissertation submitted in partial fulfilment of the requirements for the degree M Com Industrial Psychology, Faculty of Economic and Management Sciences, University of Pretoria.

Stromquist, N.P. (2017). Twenty years later: International efforts to protect the rights of higher education teaching personnel remain insufficient. MD: Education International, Brussels, Belguim.

Tessema, K.A. (2009). The unfolding trends and consequences of expanding higher education in Ethiopia: Massive universities, massive challenges. Higher Education Quarterly, 63(1), 29-45. https://doi.org/10.1111/j.1468-2273.2008.00408.x

The South African Council on Higher Education. (2016). Annual Report 2015/6. Tshwane, South Africa: Shereno Printers.

Thomas, J.D., Lunsford, L.G., \& Rodrigues, H.A. (2015). Early career academic support Evaluating mentoring networks. Journal of Higher Education Policy and Management, 37(3), 320-329. https://doi.org/10.1080/1360080X.2015.1034426

Tlou, S.S. (2014). Job insecurity, job satisfaction and general health in a higher education institution. Unpublished Doctoral thesis. Vanderbijlpark, South Africa: Department of Industrial Psychology, North-West University.

Turner, R., Spowart, L., Winter, J., Muneer, R., Harvey, C., \& Kneale, P. (2017). The lecturer should know what they are talking about: Student union officers' perceptions of teaching-related CPD and implications for their practice. Innovations in Teaching International, 54(2), 143-151. https://doi.org/10.1080/14703297.2016. 1257948

Tynan, B.R., \& Garbett, D.L. (2007). Negotiating the university research culture: Collaborative voices of new academics. Higher Education Research and Development, 26(4), 411-424. https://doi.org/10.1080/07294360701658617

Vale, R.D. (2010). It's a wonderful life: A career as an academic scientist. Molecular Biology of the Cell, 21(1), 11-14. https://doi.org/10.1091/mbc.E09-08-0678

Van Heerden, J., Bohlmann, H., Giesecke, J., Makochekanwa, A., \& Roos, L. (2007). Higher education impact: Universities in the South African economy. Pretoria, South Africa: Human Sciences.

Viljoen, J. P., \& Rothmann, S. (2009). Occupational stress, ill health and organisational commitment of employees at a university of technology. SA Journal of Industrial Psychology/SA Tydskrif vir Bedryfsielkunde, 35(1), Art. \#730, 1-11. https://doi. org/10.4102/sajip.v35i1.730

Vishnevsky, T., \& Beanlands, H. (2004). Interpreting research in nephrology nursing. Nephrology Nursing Journal, 31, 234-238.

Walker, E., \& Dewar, B. (2000). Moving on from interpretivism: An argument for constructivist evaluation. Journal of Advanced Nursing, 32, 1-12. https://doi. org/10.1046/j.1365-2648.2000.01532.x

Yin, R.K. (2003). Case study research: Design and methods (3rd ed.). Thousand Oaks, CA: Sage. 